\title{
Challenges to Growth in Tourism Industry of a Developing Country: The Case of Nigeria
}

\author{
Ndanusa, Mohammed Manzuma-Ndaaba ${ }^{1}$, Yoshifumi Harada ${ }^{1} \&$ Md. Aminul islam ${ }^{1}$ \\ ${ }^{1}$ School of Business Innovation and Technopreneurship, University Malaysia Perlis, Malaysia \\ Correspondence: Md. Aminul islam, School of Business Innovation and Technopreneurship, University \\ Malaysia Perlis, Malaysia. E-mail: amin@unimap.edu.my
}

Received: March 26, 2013 Accepted: June 18, 2014 Online Published: September 29, 2014

doi:10.5539/ass.v10n19p282 URL: http://dx.doi.org/10.5539/ass.v10n19p282

\begin{abstract}
Nigeria has the potentialities required for tourism development such as natural features and land formations, manmade creativities and artifacts and divergent heterogeneous culture, yet the industry has not grown significantly. The statistical figures in table 1 are an empirical evidence to justify low patronage in terms of international tourists visit to Nigeria. The trend will likely continue downward if urgent and drastic measures are not taken by the Government and other stake holders in the industry to improve the security situation, provide tourism facilities and embark on aggressive image laundry strategy. The researcher conceptualize the potentials and challenges of Nigeria tourism sector as discussed in extent literatures and relevant industry reports and arrived at the conclusion that Government of Nigeria most exert political will and commitment to drive the tourism industry for the development of the economy.
\end{abstract}

Keywords: tourism potentials, economic development, tourism facilities, international tourists and Government of Nigeria

\section{Introduction}

Tourism has become a phenomenon in both developed and developing economies across the globe, owing partly to bizarre of income generation, employment creation and poverty elimination potentials; and exploring development variables associated with the intangible products (Andriotis et al., 2008; Meng et al., 2008).Tourism as a displacement activity, involves being away from home on a temporary short-term visit to and stay at places of interest outside one's domicile and work. United Nation World Tourism Organization (UNWTO) however put a time limit of within a year of stay outside the environment other than your home either for business, leisure or other purposes to the definition of tourism. But strictly speaking, tourism encompasses the industry that package, facilitate, promote and delivered such travel and care for those on the move as well as the impact the visitors and host communities have on each other before, during and after the experience.

Tourism has no doubt wage enormous economic impact on all sphere of the society to become one of the fattest growing industries globally (Aliyu, Abdul Kadir, \& Aliyu, 2013). The strength of tourism performance is obvious in poverty reduction, employment generation and income redistribution effect on rural communities (Kurian, Varadharajan, \& Rajasekar, 2010). With the revolution in tourism industry, both the government and private entrepreneurs have started to optimize the opportunities of attracting tourists to their countries. In other to explore these numerous potentials that are inherent in tourism industry, many countries have started to design their regions, cities and states in a manner that will attract tourist and tourist investors (Gil \& Ritchie, 2008). The development of tourism as an alternative revenue sources is the new strategy in most countries because of its multiplier effect on other sectors of the economy, creating large volume of job for both skilled and unskilled labor (Ayeni \& Eboho, 2012).

Basically, the impacts of tourism are felt in a nation socially, environmentally and economically. At the society's level, the benefits cut across peasants, artisans and even professionals irrespective of gender, race or age bracket. Environmentally, tourism has the potentials to conserve the natural environment, preserve antiquities, historical monuments and traditional behaviors such as culture, food, language, heritage, arts and crafts. And, economically, tourism creates wealth capable of stimulating both domestic and foreign earnings of any nation from direct activities or associated businesses (NTDMP, 2006). 
However, tourism is divided into tangible and intangible assets. The physical features include: natural, socio cultural events, ethno-historical and manmade attractions; while the intangibles are the destinations image and reputation, and the technological knowhow involved in tourism development (Apostolopous \& Gayle, 2002).Tourism is perceived as a strategic medium for cultural and traditional heritage promotion to international arena thereby bringing the custodian country to international limelight (Meng et al., 2008).

\subsection{Nigeria Tourism History}

Nigeria, the giant of Africa is blessed with material, human and Natural resources such as solid mineral, crude oil deposits and natural gas with an estimated population of about 160 million people (according to 2006 census figure). Ironically, the riches does not transform to better life for the citizens as standard of living in Nigeria is below the united nation's benchmark, live expectancy ration is also low, poverty, diseases and illiteracy level is on the high side. Meaning that, Nigeria is a rich Country with poor people (APRM report, 2008). Nigeria is a multi-ethnic state endeared with rich cultures; incidentally the major cultures seem to be decimated by geographic boundaries, giving birth to distinct cultures between the 36 states and the Federal capital territory (Bola, 2010; Samuel, 2010).

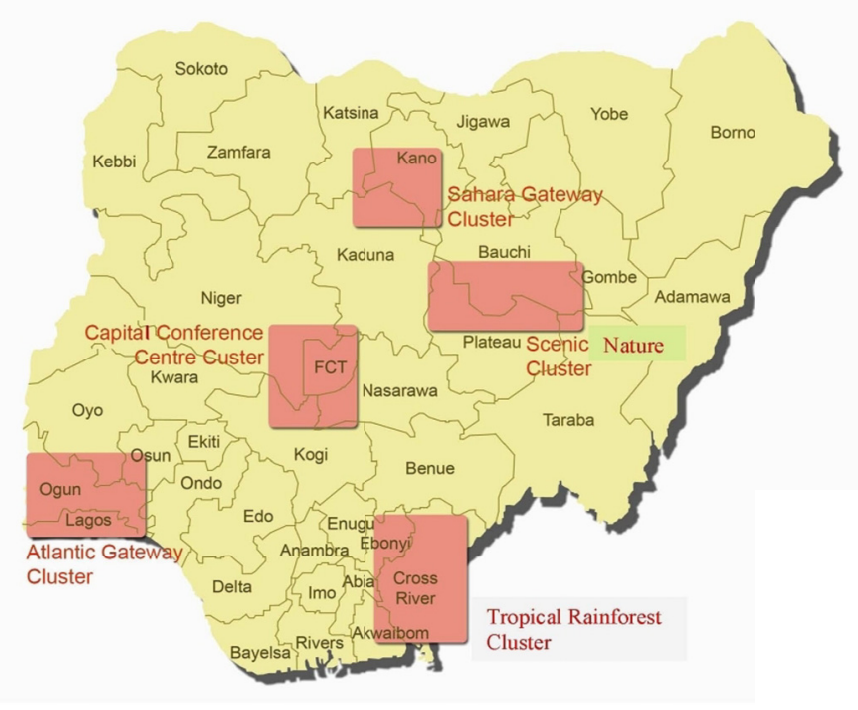

Figure 1. Map of Nigeria

Although leisure and tourism activities in Nigeria began since the Colonial era and continue till independence in 1960, government involvement in tourism only started with the establishment of Nigeria Tourism Board (NTB) in 1976 and 1990 when a national tourism policy was finally formulated and adopted (Bola, 2010). Tourism development suffered neglect throughout the military rule and only bounced back with the return of democracy in 1999. The Government repositioned tourism to occupy a strategic position in the diversification economic agenda by establishing a full fledge ministry; Ministry of Culture and Tourism and reinvigorate the moribund National Tourism development Corporation (NTDC) established since 1992 with the responsibility to register and classify all hospitality establishments in the country and ensuring that international standards are maintained while also engaging in destination promotional activities within and outside Nigeria. The Government captured tourism among the six priority areas and engaged domestic and international stakeholders including UNWTO and UNESCO to prepare a comprehensive National Tourism Development Master Plan (NTDMP) in 2006. Tourism was identified as a strategic measure for accelerated economic turnaround inculcated into the Millennium development goals. The Ministry of Culture and Tourism organized in 2005 the first Abuja Carnival as part of her promotional efforts to showcase the rich heterogeneous culture of the most populous African Nation. Government through the ministry packaged Abuja carnival to draw the attention of the world to visit Nigeria and have a feel of both natural and manmade features in its original form (Bankole, 2013). Since then, Abuja carnival has become an annual major event witnessed by tourists within Africa and beyond for a whole week usually held within the last quarter of the year (Yaradua, 2006). 
Hotel industry is one of the largest industries in the tourism sector which has played a vital role in the hospitality industry especially in providing tourist with the needed comfort in any tourist destination (Eja'Oto, Yaro, \& Iyang, 2011). The history of success or otherwise of any tourism destination will be incomplete without the role of hospitality which is regard as vital ingredient of tourism facility. However, the standard and cost of this important tourism support services is still below international best practices in Nigeria (Eja et al., 2011).

\subsection{Tourism Potentials in Nigeria}

Nigeria ranks among the most privileged nations of the world in terms of endowment of natural attractions. Such attractions include: the mountains, hills and highlands; caves and valleys (with waterfalls and water tributaries); spectacular vegetation (dense high forest, savannah and Sahel); varieties of species of wildlife, flora and fauna. Nigeria is located on the west coasts of Africa located between latitude 4 and $14 \mathrm{~N}$ and longitudes 3 and $13 \mathrm{E}$ and have an estimated landmass of $923,768 \mathrm{sq} . \mathrm{km}$ including its coastal and inland water ways. Hence, Nigeria tourist attractions are indeed very great and diverse with lots of potentials for economic transformations, poverty reduction, income redistributions and foreign direct investments. The extent to which these benefits are explored by any nation is subject to certain local conditions such as community involvement and sustainability measures (Hall, 2007). Tourism creates opportunities for local communities to benefit from their culture and natural assets through employment in tourism activities and the supply of services and goods such as food, excursions or handicrafts, to tourism businesses or directly to visitors, without having to migrate to towns in search of a better life (UNWTO, 2011). Smith (2007) argues that economic benefits of tourism is a function of competitive market drive and community involvement that can guaranty high expectations of the tourists on destination image and facilities that will promote positive words of mouth and revisit intentions by the tourists.

Nigeria has not maximized her tourism potentials simply because Government commitment in providing conducive environment and required infrastructure is inadequate. These lacks of infrastructures is worst hit in the rural areas where natural land formations and fascinating tourist's sites found themselves. Moreover, efforts at developing infrastructure to support tourism are highly insignificant, and recent efforts by the successive government are concentrated in the urban areas (Briedenhann \& Wickens, 2004). The sites and attractions location should be the focus for infrastructural development since it is the pivotal where other economic activities will revolve (Fayissa, Nsiah, \& Tadaese, 2007), to bring about desired micro and macro-economic growth in the area and by extension the Country (SEPO, 2006). In order to maximize these stimulated economic benefits, all leakages and wastages should be minimized. To achieve that, local patronage of food, drinks, souvenirs, manpower and even facilities at the site should be encouraged (Felix \& Usman, 2008).

Nigeria tourism potentials can only be utilized sustainably, if there is political will by the government in terms of providing adequate security, building roads, airports, electricity, telecommunication and even internet facilities linking the sites. And then put in place a comprehensive data base for both inbound and outbound tourists' movement and encourage active private participation in areas such as hotel accommodation, transportation and tour guide activities (Eja et al., 2011).

Tourism is a composite phenomenon and the inventory of its component factors, therefore, must go hand in hand with acknowledgement of the general development objectives and characteristics of the area or region under consideration especially now that tourism is market driven, customer satisfaction most be the concern of tourism providers (Sitikantha \& Tapan, 2001). No place is too remote to be visited. If the attractions are properly package and presented. These remote and scattered locations harbor different types of tourism system ranging from aquatic tourism to wildlife and discovery waiting exploring to the benefit of humanity (Felix, \& Usman, 2008).

All the aforementioned types of tourism are in abundance in virtually each of the thirty six (36) States in Nigeria (Eja et al., 2012). Some of the attractions are natural while others are man-made ranging from hills, fall springs, caves, lakes and mountains as well as cultural festivals, historical sites and monuments unevenly spread in Nigeria. These beautiful natural gifts and exciting festivals provide interesting places of leisure, recreation, adventure, entertainment, relaxation and curiosity (Bola, 2010). Tourism activities have been criticized as posing danger to the environment through degradation, deforestation and destruction of natural habitats in its operation and social environment. Mbaiwa, (2003) argues that there exist a complex relationship between tourism and the environment and for this reason caution should be applied in all tourism related activities especially manmade features and construction of tourism support facilities. Conscious efforts are required to guaranty replenishment and regeneration capacity of the environment in tourism development drives (Ayeni \& Ebohon, 2012). Some of the most prominent tourist attractions are classified into natural and manmade features (Eja, Iwara, Ukwayi, \& Ojona, 2012). They are: 


\subsection{Natural Features}

\subsubsection{Ocean Beaches}

Nigeria has approximately $400 \mathrm{~km}$ of Atlantic beachfront. While some sizeable portions are polluted by oil in the oil producing areas others are clean with high potentials for resort development.

\subsubsection{Nigeria Vegetation}

Ranging from the mangrove forest in the south to savannah and mountainous valleys and Sahel in the north. The thick forest in south provide natural habitat to different species of wildlife.

\subsubsection{Geographical and Geological}

Formations that attracts mountaineering, rock formations adventurers, scientific expedition, caves and waterfalls.

Waterfalls are special geographical features which have provided successful holiday resort in many parts of the world. Close to Nigeria is Victoria Falls which has been developed at both Zimbabwe and Zambia sides for tourism purposes.

\subsubsection{The Nigerian Slave Routes}

Identify the main chartered routes used for the shipment of slaves from West Africa to the new worlds between the 16thand 18th century. This trans-Atlantic slave trade is perhaps the most significant element of Nigerian and African history.

Europeans discovered the southern areas of Nigeria along its coast in the15th Century. Portuguese explorers settled in southern Nigeria and started the slave trade. The Dutch, British and other European traders later joined them in the slave business. The Slave trade flourished for about 300 years in Nigeria. Authentic proofs have been established that Nigerian slaves were crucial and dominant in the development of the Americas as the blacks of this route dominate the black population from North America to Cuba and other Caribbean Countries down to Brazil.

The route will be of interest to adventurers and also exposes how vast Nigeria family is all over the world and the importance of Nigerian culture to the entire world. It therefore will build up a good case for the relevant people to find their route in Nigeria (NTDMP, 2006).

\subsubsection{Wild life, Games Reserves and Wetlands}

Nigeria has a number of National Parks, Game Reserves and Wetlands. The Nigerian National Parks generally lack the spectacular concentration of a large wild animal population associated with National Parks elsewhere in Africa. However in terms of biodiversity, the Nigerian National Parks compare very favorably. Nigeria as a whole supports more than 274 different species of animal, 831 species of birds and about 4,600 species of plants.

\subsection{Man Made Features}

\subsubsection{Arts and Crafts}

Crafts are synonymous with Nigeria's material and superficial believes. Crafts and craft making are well integrated into the living and working patterns of people and has become part of spiritual thinking of Nigerian. It is the combination of these two elements that make a visit to a Nigerian crafts village a potentially enjoyable visitor experience. Essentially, Nigerian crafts are grouped into dye \& cotton, pottery \& ceramics, fiber crafts, bronze, brass and iron works, leatherworks, jewelry, wood carving.

\subsubsection{Festivals and Traditional Dancing}

Festivals, celebrations and dances are integral part of Nigerian culture depicting the country's native customs and traditions in a meaningful and colorful way. The range and number of local festivals and dances reflect the rich diversity that exists within Nigeria and can provide tourists with a unique opportunity to sample and flavor Nigerian culture in some of its purest forms. A typical example of such festivals is the annual Argungu fishing festival and a host of traditional and cultural events.

\subsubsection{Unique Historical Events}

Unique historical events as to the impact the Europeans made in Nigeria offer potentially very strong tourism products. Mungo Park a Scot and Richard Lemon Lander contributed immensely to exposing Nigeria to the world through the exploration of the Niger River. Both died in their exploration missions in Nigeria and their remains remain in Nigeria. Mary Slessor was a prominent Scots woman who dominated the historical scene in the primitive Nigeria (in the second half of 17th Century) particularly in Akwa Ibom and Cross River state. She elevated the status of women who were treated as "lower than cattle" in society. By this, she was about the first 
Pioneer of Women's Rights in Africa. She stopped the killing of twins who were thought to be possessed with evil spirits and banishment of their mothers in Nigeria. This is one of the greatest achievements of Mary Slesso as contained in the Nigeria Tourism Development Master Plan 2006.

\subsubsection{National Monuments, Sites and Museums}

Nigeria's cultural diversity is captured in its monuments and historic sites, which draw from its history of ancient walled cities, palaces of its traditional rulers, it's colonial past and its multi-denominational religious tradition. Each state and city has its own very distinctive monuments and historic sites all associated with the rich folklore and history of the areas. While all are of importance to the natives of the locations, many will not be of interest to international and regional tourists.

\subsection{Tourist Arrivals}

Nigeria is not a destination for most international tourists despite unique opportunities for exploration, adventure and fun seeking individuals. The reasons are not far-fetched; insecurity, low level of tourism infrastructure, political instability and host of other numerous challenges identified below. The foreigners that dominated Nigeria's tourists arrivals are mostly people that come for businesses, conference, officials on mission, and family or friend's visits. Yet there is no accurate statically recorded data of actual number of these groups of tourists and their purpose of visit to Nigeria. UNWTO have advocated the creation of tourism satellite account (TSA) to measure the economic impact and contributions to GDP arising from inbound and outbound visits in tourism sector of any country. Moreover, domestic tourism that will compliment international tourism is insignificant, partly due to low level of awareness and low income level of an average Nigerian (Awaritefe, 2007). Nigerians hardly visit any tourist destinations in the country while on vacation except for seminars, conference, meetings or political party's convention scheduled for any of the tourist locations. The average Nigerian preferred to visits friends and relations in their camphor during festivals, ceremony or holidays while the privileged government officials travelled overseas for vacation and medical checkups. (Awaritefe, 2003) which affect domestic contribution to tourism earnings

The rate of international tourist arrivals in Nigeria presented in table 1 is coined from the work of Eja, et al (2012). It shows an inconsistence percentage figure of tourist arrivals between 2008 and 2011 with values of $23.26 \%$ and $5.86 \%$. This fluctuated number in tourist arrivals may be due to the recent terrorist attack and political instability in Nigeria especially in most states with high political crises and travel advice issued by Western Countries to their citizens about visit to Nigeria. Table1 shows that tourists from Cuba and Cameroon were the major international tourists that visit Nigeria more as a tourist destination with values $23.30 \%$ and $24.21 \%$ followed by Ghana and South Africa with values of 12.19 and $10.42 \%$ while international tourists from Irish, Germany and Thailand were on the least side with values of $1.68 \%, 1.78 \%$ and $3.36 \%$ respectively.

Table 1. International tourist arrivals in Nigeria

\begin{tabular}{cccccccc}
\hline Countries & 2007 & 2008 & 2009 & 2010 & 2011 & Total & Average \% total arrival \\
\hline Cuba & 2105 & 3456 & 3145 & 994 & 499 & 10199 & 23.30 \\
South Africa & 1231 & 975 & 1045 & 995 & 365 & 4561 & 10.42 \\
Brazil & 954 & 457 & 394 & 445 & 234 & 2484 & 5.67 \\
Ghana & 2111 & 1044 & 1124 & 904 & 153 & 5336 & 12.19 \\
India & 1011 & 578 & 2341 & 475 & 105 & 4510 & 10.30 \\
USA & 734 & 754 & 1411 & 95 & 99 & 3093 & 7.06 \\
Cameroon & 3456 & 2456 & 3345 & 356 & 984 & 10597 & 24.21 \\
Thailand & 945 & 245 & 154 & 75 & 54 & 1473 & 3.36 \\
Irish & 445 & 105 & 95 & 65 & 27 & 737 & 1.68 \\
Germany & 345 & 111 & 204 & 74 & 45 & 779 & 1.78 \\
Average \% & 30.49 & 23.26 & 30.29 & 10.11 & 5.86 & 43769 & 100 \\
\hline
\end{tabular}

Source: Field Survey, 2012. Research conducted by Eja, et at 2012. 


\section{Challenges of Tourism Sector in Nigeria}

Having analyzed the vast and rich tourism potentials in Nigeria and its high chances of fighting poverty, diversify the mono economy (oil), job creation, income redistribution and environmental preservation, yet the milk and honey is allowed to flourish untapped (Eja \& Ajake, 2005). Both the Government and private investors (domestic and foreign) are constraint in their investment drive due to some or all of the following predicaments (Aniah, 2006):

\subsection{Current Markets}

Industry representatives indicated that almost $99 \%$ of international tourism in Nigeria is business or conference related. The main generating markets are Great Britain, Europe, Africa/India, and neighboring West Africa States (Eja, et al., 2012). Business tourism is also a mainstay of domestic tourism and "holiday taking culture" has yet to be developed in Nigeria (Bola, 2010). In view of the above visitors, the supporting infrastructural development is far below average for their comfort and taste both at the attraction sites and the intangible services such as; accommodation, transportation, food \& beverages etc (Zeithaml et al.). Therefore, they will rather prefer to stay put on their business concerns and or conference venue. Thus, drastically reduced the economy of scale that comes with these visits.

\subsection{Product Development Opportunities - New Markets}

Cultural tourism was identified as an aspect of tourism with potential for development. Particularly important in this regard is the opportunity to capitalize on Nigeria's rich and diverse culture in general terms, and more specifically, target the Nigeria Diaspora with a tourism offer based on the slave routes (Eja, 2010). People also identified rural/village tourism, particularly in Northern Nigeria, where support is more likely to be achieved for a 'quieter' form of tourism. Other types of tourism considered to have potential included culture, rural, adventure, coast/beach and family holiday for the domestic market (Larry, 2005). Historians and adventure tourists will be delighted to dig into the significant of these discoveries but the security situation and Nigeria image abroad are some of the impediments.

\subsection{Tourism Development Component}

The need for a strategic approach to tourism is identified as the most important factor in facilitating the development of sustainable tourism in Nigeria. Investment in tourism and particularly the supporting infrastructure is considered to be a priority. The need for professional ground handling arrangements is also acknowledged (Gbadel, 2007). Tourism development is as old as Nigeria history, but is a sector fondly remembers in theory rather than practice. There is no clear cut evolution of the sector and these greatly scarred away potential investors.

\section{Investment and Incentives: The Enabling Environment}

A major driver of growth in any economy is the annual capital base growth or capital formation. Over the past 40 years, Nigeria's capital base has been growing at only 0.1 percent per annum, which made the economy one of the slowest growing in the world. Nigeria has been trapped in a low savings, low investment, low growth logjam. Growth in the past five years has been insufficient to make any dent on poverty. The public sector, despite efforts to diversify the economy, is still the dominant employer and the private sector is still sluggish in terms of capital investment (Kester, 2007).

Low productivity mitigates against economic growth and investment and hence an increasing value added to the economy with inevitable consequences on workforce employment, remuneration and purchasing power. Tourism and recreation is an area of discretionary spending. With low growth in the economy, the rise in discretionary spending levels (those not required for basic living) will remain miniscule. This situation does not provide a solid base for the growth in domestic tourism in the immediate future (NTDMP, 2006). As evidence in the article by Eja 2007, despite the huge potentials in tourism, Cross River state contributed about 8\% to GDP in 2005 .

The development of tourism is often view to have direct relationship to economic growth (Lee \& Kwon, 1995). But Nigeria as an export driven economy is expected to benefit on a large scale from tourism related components of international trade, however, the following gaps most be reduced or closed before this can be realized;

Security, Infrastructural amenities, Promotion and awareness, Funding and financing, Attitude and image

Each of the above listed components constituted the major challenges to tourism development in Nigeria desired for this study.

3.1 The infrastructures for instance, such as road network and various means of transportations, the international and domestic airports, telecommunication and internet access, tour guide and efficient road signs \& symbols, 
hotel accommodation and other axillaries services and perceived destination image all have positive relationship with the overall tourism performance. Nigeria today is either these essential requirements are lacking or in bad condition.

3.2 Similarly security of lives and properties is fast deteriorating, obvious cases of armed robbery, kidnapping, assassination ,suicide bombing and other related crimes have negative relationship with tourism performance most especially on tourist satisfaction and repeat visit (Johnson, 2001). Virtually all parts of Nigeria is facing one form of security challenge or the other ranging from kidnapping in East, hostage taking in the South- South, armed robbery in the West and Boko Haram terrorism in the North.

3.3 Government funding as priority project will enhanced effective and accelerated development in the tourism sector thereby opening the windows of opportunities resulting in positive performance. Closely related to these are the lending policies of the financial institutions which can trigger aggressive transformation in the sector leading to satisfactory performance. And covertly, reverse will be the case if the Government neglects the industry and the Banks and other related institutions are ash in their policies, this will slow down investment and development of the sector resulting in low performance. The government of Nigeria is only paying lip services to the issue of tourism development without any commensurable commitment in terms of enabling environment and direct investment in the sector.

3.4 Packaging and showcasing of Nigeria tourism products is at its lowest. No information about attractions and other places of leisure at international events, average visitors to Nigeria usually get astonished when he or she stumbles into places of interest and sites of wonders. This lack of adequate information is a minus on tourism performance. This is to say, the marketing image of destination is at its lowest (Chang, 1997) and unless some drastic measures are adapted, little or no transformation will be achieved.

3.5 Attitudinal change is required by the personnel connected with this very important internationally driven industry. Of course, Nigerians are humble and diligent yet with high potentials of fraud and corrupt related tendencies. The ground staffs at the points of entry, transportation, accommodations and tourist sites are expected to be courteous, polite and appealing both in physical appearance and manners (Zeithaml et al). All these virtues will transform to tourist satisfaction and by extension tourism performance.

\section{Conclusion}

Nigeria is evidently blessed with a lot of tourist sites with the potentials of raising revenue for the nation but unfortunately this is not maximally tasked as tourism in Nigeria is relegated to the background.

The author attempted to $x$-ray some of the potentials and challenges of tourism development in Nigeria with a view to explore the poverty alleviation strength in tourism development for the overall benefits to the people. World over tourism is rated as the second largest growing business area after information technology contributing $5 \%$ of the world GDP and $6 \%$ of the world's exports in services (WTO, 2011). Investment in tourism sector if properly managed with a strong focus on poverty alleviation, it can directly benefit the poorer groups through employment of local people in tourism enterprises, goods and services provided to tourists, or the running of small and community-based enterprises, etc at the local level while stimulating foreign earnings through reduction on taxes and return on investment. Tourism investment is also used as conservation and preservation strategy of the environment, historical, archaeological and religious monuments, poverty eradication and elimination of social vices, stimulation of cultural practices, folklore, traditions, art and craft cuisines, (Osy Kings, 2013). Research has shown that tourism in many developing and least developed countries is the most viable and sustainable economic development option rated as the first or second source of export earnings in 20 of the world's 48 least developed countries and in some small countries notable islands accounted for over $25 \%$ GDP. Part of this income trickles down to different groups of the society thereby redistributing income. In the global economy, even countries with poor level of infrastructure and facilities are said to be able to attract investors to their country for tourism development which implies that with enabling environment, Nigeria is set to take her rightful position in Africa (NTDC, 2007). Tourism acts as an engine for development through foreign exchange earnings and the creation of direct and indirect employment.

If country like Greece can depend on tourism solely to develop the economy, create employment, and reduce poverty (Andriotis et al., 2008) then, the chance of Nigeria is bright in this regard as one of the strategies to facilitate the attainment of Millennium Development Goals.

\section{References}

African Peer Review Mechanism (APRM). (2008). Country Preview Report: Federal Republic of Nigeria. Retrieved from http://www.nepad.org/economicandcorporategovernance 
Aliyu, B. B., Abdul Kadir, H. D., \& Aliyu, O. A. (2013). The relationship between Tourist Expectation, Perceived quality and Satisfaction with Tourism Product. Retrieved from http://www.medwelljournals.com/ abstract/?doi=ibm.2013.158.164

Andriotis, K., George, A., \& Athanasios, M. (2008). Measuring tourist satisfaction: A factor-cluster segmentation approach. Retrieved from http://jvm.sagepub.com/content/14/3/221.

Awaritefe, O. D. (2004). Destination Image differences between prospective and actual tourist in Nigeria. Retrieved from http://jvm.sagepub.com/content/10/3/264.full.pdf

Bankole, A. O. (2013). Harnessing cultural heritage for tourism development in Nigeria; Issues and prospects. Retrieved from http://webcache.googleusercontent.com/search?q=cache:http://www.gifre.org/admin/papers/ gjcmp/HARNESSING.pdf

Bola, O. A. (2010). Peace and Tourism in Nigeria. Retrieved from http://www.responsibletravel.org/resources/ documents/reports/TPhil

Briedenhann, J., \& Wickens, E. (2004). Tourism Routes as a Tool for the Economic Development of Rural Areas-Vibrant Hope or Impossible Dream? Tourism Management, 25, 71-79. http://dx.doi.org/10.1016/ S0261-5177(03)00063-3

Eja, E., \& Ajake, A. (2005). Tourism potentials as a strategy for sustainable development of the Niger Delta Region of Nigeria. International Journal of sociology and anthropology, 2(1), 53-60. Retrieved from http://jeteraps.scholarlinkresearch.org/articles/Success\%20Factors\%20Determining\%20Nigeria\%20as\%20a \%20Tourist\%20Destination.pdf

Eja, E. I., Oto, Y. E., Yaro, M. A., \& Inyang, I. O. (2011). Impact of Hospitality Industry in poverty alleviation in a tourist destination: Cross River State Scenario. Mediterranean journal of social sciences.

Eja, E. I., Ukwayi, J. K., \& Ojong, F. E. (2012). Success factors determining Nigeria as a tourist destination. Retrieved from http://jeteraps.scholarlinkresearch.org/abstractview.php?id=587

Ernest Samuel, G. C. (2010). Towards the implementation of the Nigeria cultural policy for the promotion of culture in Nigeria. Retrieved from http://www.ajol.info/index.php/cajtms/article/view/76597

Fayissa, B., Nsiah, C., \& Tadasse, B. (2008). The Impact of Tourism on Economic Growth and Development in Africa. Tourism Economics, 14, 807-8188. http://dx.doi.org/10.5367/000000008786440229

Felix, O., \& Usman, A. R. (2008). Sustainable tourism development in Africa: The imperative for tourists/host Communities'securities. Retrieved from http://www.unilorin.edu.ng/publications/raheemua/ARC

Ghadel, L. (2007). Tourism and politics-policy and place. Retrieved from http://epubs.surrey.ac.uk/1100/1/ airey_i

Gil, S. M., \& Ritchie, J. R. (2008). Understanding the museum image formation process: A comparison of residents and tourists. Retrieved from http://jtr.sagepub.com/content/47/4/480

Government of the Federal Republic of Nigeria, UNWTO, UNDP, Tourism Development International, Nigeria Tourism Development Master Plan: Institutional Capacity Strengthening to the Tourism Sector in Nigeria, Final Report, Executive Summary. (2006, January). Retrieved from http://web.ng.undp.org/publications/ enviroment/tourism_masterplan.pdf

Hall, C. M. (2007). Pro-poor Tourism: Who Benefits: Perspectives on Tourism and Poverty Reduction, Channel View Publications. Retrieved from https://www.academia.edu/151599

Johnson, R. (2001). Identifying competitive strategies for successful tourism destination development. Journal of Hospitality and leisure marketing, 31(1), 37-45. Retrieved from http://books.google.com.my/books?id= WIRBX5hBW_UC\&pg=PA184\&lpg=PA184\&dq

Kester, N. (2003). Destination product and impact on visitors. Tourism Management, 21(1), 452. Retrieved from https://www.google.com/search?q=Kester\%2C+N+(2003

Larry, E. (2005). The Cross River State Tourism Vision and Policy Mofinews, 3 (pp. 44, 48-49). Retrieved from https://www.google.com/webhp?sourceid=chrome-instant\&rlz=1C1AVSF

Mbaiwa, J. E. (2003). The Socio-Economic and Environmental Impacts of Tourism Development on the Okavango Delta North-Western Botswana. Arid Environments, 54, 447-467. http://dx.doi.org/10.1006/jare. 2002.1101

Meng, F., Tepanon Y., \& Uysal, M. (2008). Measuring tourist satisfaction by attribute and motivation . 
Nigeria Tourism Development Corporation. (2007). Nigeria Tourism Development Corporation (NTDC) Guide for Local Authorities on developing sustainable tourism. Retrieved from http://tourism.gov.ng/aboutntdc/contacts.

Awaritefe, O. D. (2007). Tourist Characteristics and Demand for Tourism Destination Products in Nigeria, Tropical Africa. Tourism Today: The Journal of the College of Hotel Management, (7). Retrieved from http://www.prd.uth.gr/uploads/publications/2007/78a80daa649a56612c82c47fd1431e9dc767aec9.pdf

Kings, O. (2013). Abuja Carnival Should Be Developed Into a Business- Chief Edem Duke. Retrieved from http://newsfield.net/index.php/top-news/national-news/48

Sitikantha, M., \& Tapan, P. K. (2001). Socio Political Barrier to Tourism Mark. In South Asia: Indian Institute of Travel and Tourism Management. Bhubaneswar. Retrieved from http://cabdirect.org/abstracts/20043052683. html;jsessionid=25831793C03F18C1C04B24F2E508DD92

Smith, A. (2007). Wealth of Nations Cosimo Classics. Retrieved from http://books.google.com.my/books/about/ Wealth_of_Nations.html?id=UrwxbIwEijgC\&redir_esc $=\mathrm{y}$

Sujitha, A. K., Varadharajan, R., \& Rajasekar, N. (2010). Tourism Employment: Challenges and strategic opportunities. Retrieved from http://bccaarmel.ac.in/main/downloads/Article_5.pdf

Yaradua, S. (2006). Tourism's Contribution to Development. The Parliamentarian, (2). Retrieved from http://www.responsibletravel.org/resources/documents/reports

Fakiyesi, T. (2008, June 19-20). Economic Acceleration of Nigeria through the Development of Tourism Industry. A paper presented at the National Workshop on Mainstreaming ICT into National tourism Development Plan, Nicon Luxury Hotel, Abuja, Nigeria. http://www.responsibletravel.org/resources/documents/reports.

UNWTO. (2007, September). International Recommendations on Tourism Statistics (IRTS). Provisional Draft, Revision 5, Madrid. Retrieved from http://unstats.un.org/unsd/trade/IRTS/IRTS\%202008\%20unedited.pdf

UNWTO. (2011). Tourism and poverty reduction. Retrieved from http://step.unwto.org/content/tourism-andpoverty-alleviation-1

Zeithaml, V. A., Parasuraman, A., \& Berry, L. L. (1985). Problems and strategies in services marketing. J. Market., 49, 33-46. http://dx.doi.org/10.2307/1251563

\section{Copyrights}

Copyright for this article is retained by the author(s), with first publication rights granted to the journal.

This is an open-access article distributed under the terms and conditions of the Creative Commons Attribution license (http://creativecommons.org/licenses/by/3.0/). 